\title{
Prey, parasites and pathology associated with the mortality of a juvenile gray whale (Eschrichtius robustus) stranded along the northern California coast
}

\author{
Murray D. Dailey ${ }^{1, *}$, Frances M. D. Gulland ${ }^{1}$, Linda J. Lowenstine ${ }^{2}$, Paul Silvagni ${ }^{2}$, \\ Daniel Howard ${ }^{3}$ \\ ${ }^{1}$ The Marine Mammal Center, 1065 Fort Cronkhite, Sausalito, California 94965, USA \\ ${ }^{2}$ Veterinary Medicine Teaching Hospital, Veterinary Pathology, Microbiology And Immunology, University of California \\ at Davis, Davis, California 95616, USA \\ ${ }^{3}$ Gulf of the Farallones National Marine Sanctuary, San Francisco, California 94123, USA
}

\begin{abstract}
An eastern Pacific gray whale (Eschrichtius robustus) stranded off Pelican Point, Tomales Bay, California, USA, was examined for physiological parameters, prey, parasites and associated pathology. The whale was emaciated, and hematological examination revealed an elevation in hematocrit, serum sodium, potassium, electrolyte values and hypoglycemia. Parasites recovered included 5 species, 1 ectoparasite (Cyamus scammoni), and 4 helminths (Anisakis simplex, Ogmogaster antarcticus, Ogmogaster pentalineatus, Bolbosoma balanae) with the latter causing multifocal transmural abscesses. Histological examination indicated severe acute lung congestion, minimal, multifocal, lymphocytic, interstitial myocarditis, and mild hepatocellular and Kupffer cell hemosiderosis. The prey taxa present in the stomach indicated the whale was feeding on hard bottom communities prior to death.
\end{abstract}

KEY WORDS: Cetacean stranding $\cdot$ Pacific gray whale $\cdot$ Eschrichtius robustus $\cdot$ Hematology $\cdot$ Pathology $\cdot$ Parasites $\cdot$ Prey species

\section{INTRODUCTION}

The eastern Pacific gray whale Eschrichtius robustus typically migrates annually between the summer feeding grounds of the Bering Sea to the protected lagoons of Baja California to breed in late winter (Scammon 1869, Pike 1962, Rice \& Wolman 1971). Although most whales do not feed during the migrations, some individuals remain at coastal locations between Mexico and Alaska during the summer and have been observed feeding (Sund 1975, Oliver et al. 1984, Sumich 1984, Darling et al. 1998). Information on prey species

*E-mail: daileym@tmmc.org at differing locations is mostly based on sediment sampling, and identification of material in mud plumes and fecal samples. Direct stomach sampling is difficult, although some data are available (Zimushko \& Lenskaya 1970, Rice \& Wolman 1971, Nerini 1984). The significance of prey species in stomach contents of stranded whales is unclear, as these individuals may have been behaving atypically prior to death. Every year, a number of whales strand along the migration route, yet the cause of death is rarely determined due to logistical difficulties. The role of parasitic disease as a factor in cetacean strandings is speculative (Dailey \& Stroud 1978, Dailey \& Walker 1978, Geraci 1978). During 1998, there was a relative increase in the number of dead gray whales observed along the migration 
route from Mexico to Alaska (Rowles 1999). The factors involved in this increase are currently unclear, as few whales have been thoroughly examined. This report describes the hematology values, pathology, prey and parasites in a juvenile, male gray whale that stranded in northern California, USA, and describes several new host-parasite associations.

\section{MATERIAL AND METHODS}

On 26 June 1999, an emaciated gray whale was observed rolling, apparently unable to right itself, and unresponsive to touch, off Pelican Point, Tomales Bay, California. Blood was collected from the ventral margin of the peduncle using an 18 gauge $3.5 \mathrm{inch}(8.8 \mathrm{~cm})$ needle into vacutainers containing ethylene-diaminetetra-acetic acid (EDTA) or serum separator gel (Vacutainer, Becton-Dickinson, Franklin Lakes, NJ). A complete blood count was performed on the EDTA sample using an automated cytometer (ABC Vet Analyzer, Heska, Fort Collins, CO), and serum biochemistry values were determined using an Olympus 5200 analyzer (Olympus, Irving, TX). The whale was then euthanized with $500 \mathrm{cc}$ pentobarbital administered intravenously into the same vein. A gross necropsy was performed on the beach with samples of all organs fixed in $10 \%$ formalin. Subsamples of stomach contents and parasites were recovered for transport to the laboratory at The Marine Mammal Center, Sausalito, California. Fixed tissues were embedded in TissuePrep (Fisher Scientific, Fairlawn, NJ), sectioned at $5 \mu \mathrm{m}$, and stained with hematoxylin and eosin for examination by light microscopy. The intestine was measured and divided into $1 \mathrm{~m}$ lengths and subsampled for parasite distribution within the gut. Trematodes and acanthocephalans were fixed in an alcohol, formalin and acetic acid mixture (Dailey 1996), stored in $70 \%$ ethanol, stained with Semichon's carmine, dehydrated in ethanol, cleared in Hemo-De (Fisher Scientific) and mounted in Canada balsam. Nematodes were fixed in hot $70 \%$ ethanol, then cleared in lactophenol for temporary mounts and identification. Whale lice were placed in $70 \%$ ethanol until examination. Voucher specimens were deposited in the United States National Parasite Collection (USNPC), Beltsville, Maryland.

\section{RESULTS}

\section{Gross pathology and parasitology}

The whale was an immature male, $822 \mathrm{~cm}$ long, with a blubber depth at the mid-lateral flank of $8 \mathrm{~cm}$. There was severe skeletal muscle and blubber atrophy, resulting in prominent dorsal 'knuckles' and transverse processes of vertebrae in the lumbar region, and a concavity between the skull and dorsum. A heavy infestation of Cyamus scammoni Dall, 1872, was found diffusely on the skin and flukes, and more severely within ulcerated areas of skin on the leading edges of the pectoral fins and flukes. The stomach was distended with food material (Table 1, entire contents) and massive numbers of the ascaridoid Anisakis simplex Rudolphi, 1809. The gastric mucosa was congested and histologically showed a mild, superficial, multifocal lymphocytic gastritis.

Multifocal transmural abscesses were observed along the first $75 \mathrm{~m}$ of ileum (Fig. 1). Within each abscess was an encapsulated proboscis of the acanthocephalan, Bolbosoma balanae Gmelin, 1790 (Fig. 2). Culture of the abscesses using routine bacterial culture methods (Thornton et al. 1998) produced Edwardsiella tarda, Escherichia coli and Clostridium perfringens. Acanthocephalans also were observed free in the lumen of the ileum, but these were bodies only without attachment organs (Fig. 3). A massive number of the trematode Ogmogaster spp. were found along the entire intestinal tract with maximum numbers observed in the rectum. Both O. antarcticus Johnston, 1931 and $O$. pentalineatus Rausch \& Fay, 1966, were found free in the intestinal lumen. $O$. antarcticus $(n=100)$ ranged in

Table 1. Eschrichtius robustus. Stomach contents from a gray whale stranded in Tomales Bay, California, June 1999

\begin{tabular}{|c|c|c|c|}
\hline Prey & No. & $\begin{array}{l}\text { Volume } \\
(\%)\end{array}$ & $\begin{array}{l}\text { Mean size } \\
\quad(\mathrm{mm})\end{array}$ \\
\hline \multicolumn{4}{|l|}{ Algae } \\
\hline Phyllospadix scouleri & & 50 & \\
\hline Cystoceira osmundacea & & 3 & \\
\hline Nereocystis leutkeana & & 3 & \\
\hline Articulated coralline algae & & 0.1 & \\
\hline \multicolumn{4}{|l|}{ Hydroids } \\
\hline Aglaophenia sp. & & 0.1 & \\
\hline Abietinaria sp. & & 0.1 & \\
\hline \multicolumn{4}{|l|}{ Isopods } \\
\hline Sphaeromatidae & 4 & 0.1 & 3.5 \\
\hline Idotea fewkesi & 64 & 1 & 12.5 \\
\hline Synidotea sp. & 3 & 0.1 & 8 \\
\hline \multicolumn{4}{|l|}{ Amphipods } \\
\hline Jassa spp. & 1040 & 8 & 6 \\
\hline Ischyrocerus sp. & 560 & 4 & 6.5 \\
\hline Hyale freguens & 144 & 1 & 6 \\
\hline \multicolumn{4}{|l|}{ Gammarid amphipod } \\
\hline \multicolumn{4}{|l|}{ Other } \\
\hline Phyllocaetopteris sp. & & 0.1 & \\
\hline Metacapiella kennerlyi & 440 & 3 & 11 \\
\hline Heptacarpus taylori & 2 & 0.1 & 8 \\
\hline Cancer spp. & 120 & 0.1 & \\
\hline Bryozoan fragments & & 0.1 & 5 \\
\hline
\end{tabular}


Fig. 1. Eschrichtius robustus. Multifocal abscesses on the external surface of a stranded gray whale intestine. Scale bar $=1 \mathrm{~cm}$

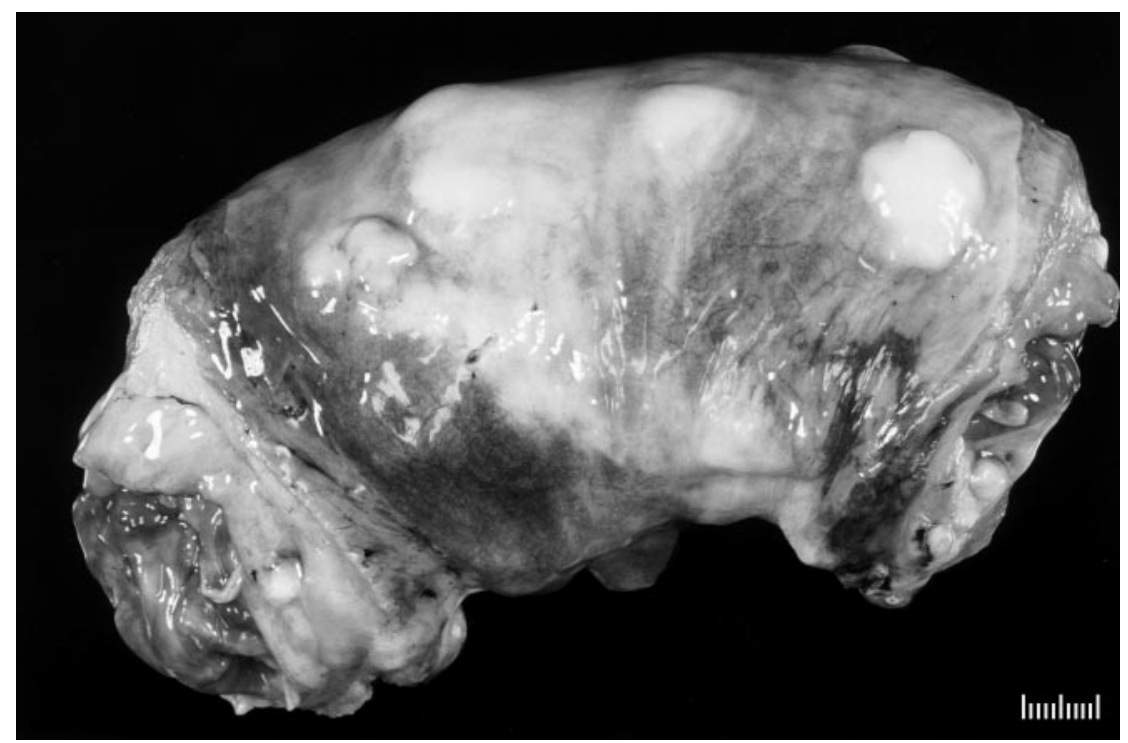

length from 3.5 to $9.2 \mathrm{~mm}$ (mean $=6.5)$, contained 11 to $15($ mean $=13.5)$ ventral ridges with 27 to 33 (mean $=$ 29.5) marginal body crenulations. O. antarcticus comprised $94 \%$ of the total subsample collected. O. pentalineatus were of 2 morphotypes: small $(\mathrm{n}=2)$ with marginal body crenulations and large $(n=12)$ with smooth marginal body. Both had 5 ventral ridges.

\section{Hematology}

Red cell parameters were similar to published mean values from a sample of 9 individuals (Bossart \& Dierauf 1990), although the hematocrit was elevated (Table 2). Serum biochemistry analysis revealed what appear to be elevations in sodium, potassium, other

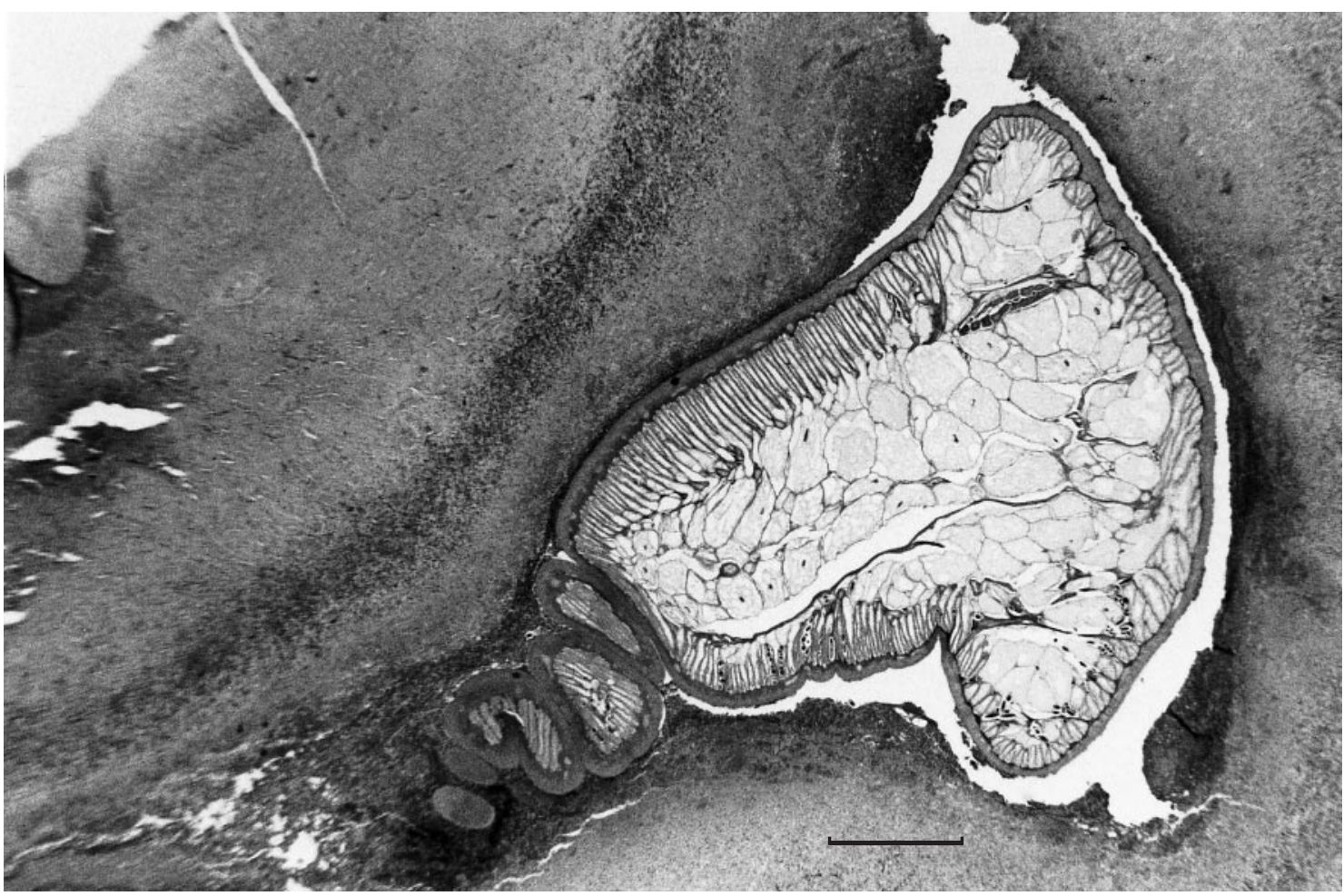

Fig. 2. Encapsulated proboscis of Bolbosoma balanae in the instestinal wall of a stranded gray whale. Scale bar $=0.25 \mathrm{~mm}$ 


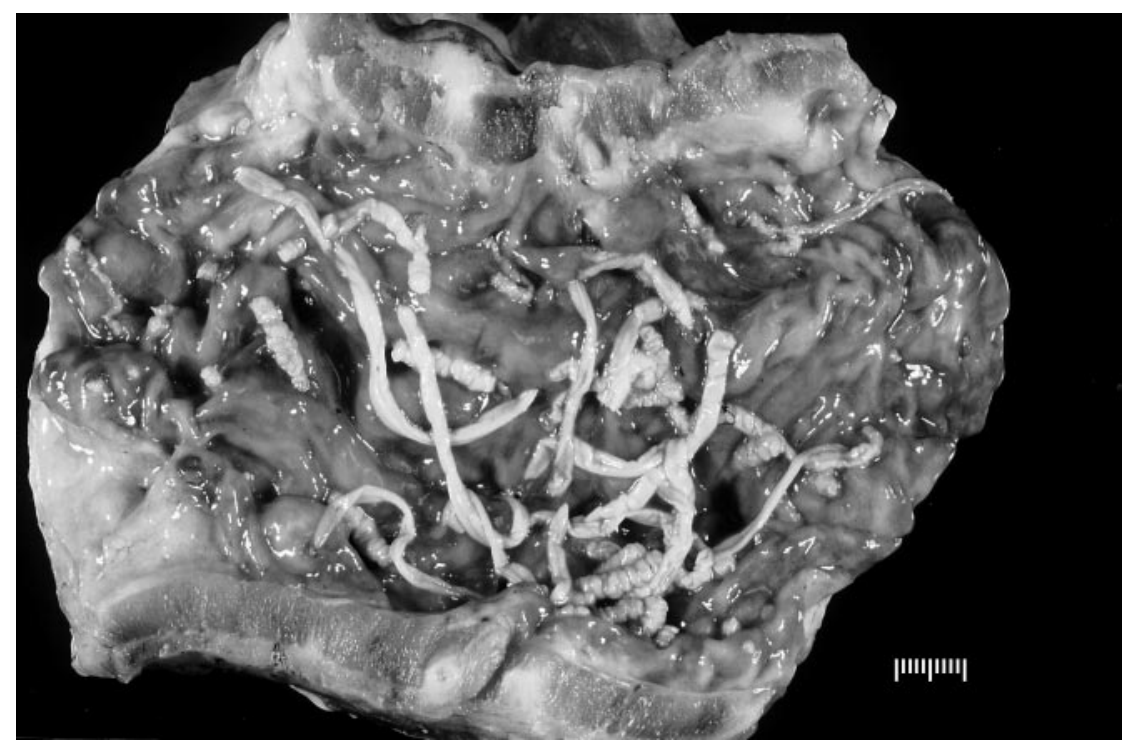

Fig. 3. Bolbosoma balanae unattached in the lumen of the intestine of a stranded gray whale. Scale bar $=1 \mathrm{~cm}$

electrolytes and evidence of hypoglycemia, as well as low alkaline phosphatase, albumin and triglyceride levels (Table 2).

\section{Histology}

On histological examination of tissues, severe acute congestion of the lungs was detected. There also was minimal, multifocal, lymphocytic, interstitial myocarditis, and mild hepatocellular and Kupffer cell hemosiderosis. There was zymogen depletion in the pancreas, and lymphoid depletion in the spleen.

\section{DISCUSSION}

The emaciated body condition of this whale indicates that it was starving, and the hematologic and serum biochemistry changes are similar to those observed in domestic animals in association with food deprivation. However, the full stomach and the nature of the contents suggest that this whale was feeding prior to death. The taxa present (Table 1) suggest it was feeding on hard bottom communities, which is unusual as amphipod crustaceans from soft sediment habitats generally are considered the predominant prey, although a variety of prey species ranging from sardine to plankton have been reported (Pike 1962, Nerini 1984, Oliver et al. 1984, Darling et al. 1998). The relative roles of parasitism and malnutrition in causing weight loss are unclear. Malnutrition is well documented to increase susceptibility to infection (Gershwin et al. 1985), while the massive intensity of infection and the associated intestinal abscesses probably de- creased intestinal motility and digestion. The zymogen depletion in the pancreas suggests chronic malnutrition had occurred prior to death.

The paucity of published normal values for gray whale hematology and serum biochemistry make interpretation of blood results subjective (Gilmartin et al. 1974, Reidarson, McBain \& Yochem unpubl.). However, the extreme differences in electrolyte values from published values from healthy cetaceans of other species (Tursiops truncatus, Thomson \& Geraci 1986), and from values reported for ' $\mathrm{JJ}$ ', the gray whale rehabilitated in 1998 (Reidarson et al. unpubl.), suggest that this whale was in a state of extreme electrolyte imbalance when stranded. The predominance of neutrophils, lack of eosinophils despite degree of parasitism and the low total leukocyte count are typical of the hematologic stress response observed in T. truncatus (Thomson \& Geraci 1986). The relatively low values for albumin, triglycerides and alkaline phosphatase may be useful indicators of poor nutritional status.

Previous reports of acanthocephalans from Eschrichtius robustus included 4 species of the genus Corynosoma (C. septentrionalis Treshchev, 1966; C. semerme Forssell, 1904; C. stromosum Rudolphi, 1802 and $C$. validum Van Cleave, 1953), all collected from whales off the Chukotskiy Peninsula in the Arctic (Rice \& Wolman 1971, Dailey \& Brownell 1972). Rice \& Wolman (1971) mentioned 2 specimens of Bolbosoma sp. from the small intestine of an immature male captured on 3 April 1968. The authors do not give the specific location of this whale, but one can assume it was probably the Seattle, Washington, area. They described one acanthocephalan as loosely attached to the mucosa; the head of the other was imbedded in a small, thickwalled, pus-filled cyst in the mucosa. Given the simi- 
Table 2. Eschrichtius robustus. Hematology and serum biochemistry values from a gray whale stranded in Tomales Bay, California, June 1999

\begin{tabular}{|ll|}
\hline Parameter & Value \\
\hline Erythrocytes & $3.2 \times 10^{6} \mathrm{l}^{-1}$ \\
Hemoglobin & $14.0 \mathrm{~g} \mathrm{dl}^{-1}$ \\
Hematocrit & $49.6 \%$ \\
Mean cell volume & $155 \mathrm{fl}$ \\
Mean cell hemoglobin & $43.7 \mathrm{pg}$ \\
Mean cell hemoglobin concentration & $28.2 \mathrm{~g} \mathrm{dl}^{-1}$ \\
Platelets & $150 \times 10^{3} \mathrm{~mm}^{-3}$ \\
Leukocytes & $4.60 \times 10^{3} \mathrm{~mm}^{-3}$ \\
Lymphocytes & $2.48 \times 10^{3} \mathrm{~mm}^{-3}$ \\
Monocytes & $0.92 \times 10^{3} \mathrm{~mm}^{-3}$ \\
Neutrophils & $1.38 \times 10^{3} \mathrm{~mm}^{-3}$ \\
Eosinophils & $0.92 \times 10^{3} \mathrm{~mm}^{-3}$ \\
Sodium & $192 \mathrm{meq}^{-1}$ \\
Potassium & $6.1 \mathrm{meq}^{-1}$ \\
Chloride & $161 \mathrm{meq}^{-1}$ \\
Blood urea nitrogen & $58 \mathrm{mg} \mathrm{dl}^{-1}$ \\
Creatinine & $0.3 \mathrm{mg} \mathrm{dl}^{-1}$ \\
Glucose & $14 \mathrm{mg} \mathrm{dl}^{-1}$ \\
Calcium & $13.7 \mathrm{mg} \mathrm{dl}^{-1}$ \\
Phosphorus & $4.1 \mathrm{mg} \mathrm{dl}^{-1}$ \\
Uric acid & $1.0 \mathrm{mg} \mathrm{dl}^{-1}$ \\
Total protein & $5.7 \mathrm{~g} \mathrm{dl}^{-1}$ \\
Albumin & $1.8 \mathrm{~g} \mathrm{dl}^{-1}$ \\
Globulin & $3.9 \mathrm{~g} \mathrm{dl}^{-1}$ \\
Bilirubin & $0.4 \mathrm{mg} \mathrm{dl}^{-1}$ \\
Direct bilirubin & $0.1 \mathrm{mg} \mathrm{dl}^{-1}$ \\
Indirect bilirubin & $0.3 \mathrm{mg} \mathrm{dl}^{-1}$ \\
Gamma glutamyl transferase & $7 \mathrm{IU} \mathrm{l}$ \\
Lactate dehydrogenase & $409 \mathrm{IU} \mathrm{l}^{-1}$ \\
Aspartate transaminase & $279 \mathrm{IU} \mathrm{l}^{-1}$ \\
Alanine transaminase & $20 \mathrm{IU} \mathrm{l}^{-1}$ \\
Alkaline phosphatase & $39 \mathrm{IU} \mathrm{l}^{-1}$ \\
Iron & $109 \mathrm{mg} \mathrm{dl}^{-1}$ \\
Cholesterol & $339 \mathrm{mg} \mathrm{dl}^{-1}$ \\
Triglycerides & $22 \mathrm{mg} \mathrm{dl}^{-1}$ \\
& \\
\hline & \\
& \\
\hline
\end{tabular}

larity of attachment and host reaction to those found in this study, they were probably describing $B$. balanae. Van Cleave (1953) stated that the definitive host in North America for B. balanae is 'an undetermined species of whale taken at Seattle, Washington, April 1, 1918.'

Acanthocephalan species for which life cycles have been confirmed by laboratory infections require vertebrates for definitive hosts and arthropods as intermediate hosts. The life cycle of Bolbosoma spp. is not known. However, Rice \& Wolman (1971) stated that the life cycles of a few species of Corynosoma are known and all of these involve crustaceans as a first, and fishes as a second, intermediate host. Nickol (1985) writes that no species of acanthocephalan has been demonstrated to require more than the arthropod intermediate host in order to be infective to the vertebrate host. Schmidt (1985) is in agreement with this statement in presenting the life cycles of 5 species of
Corynosoma, all from marine mammals, in which he lists fishes only as a transport or paratenic host. Gammarid amphipods are listed as common arthropod intermediate hosts for acanthocephlans (Schmidt 1985). Benthic, gammarid amphipods are fequently found on sea grasses (Sumich 1992), and were the most abundant organisms, by volume, found in the stomach (Table 1), lending validity to the transmission of $B$. balanae by this method in California waters.

The unusual feature of Bolbosoma balanae, not to shed eggs individually but have them leave the definitive host only in the body of the passed females to be released upon deterioration or when scavenged, would tend to enhance transmission. Observations on acanthocephalans of genus Polymorphus, in ducks, where the entire body of the gravid female is shed, confirmed that numerous arthropods are attracted to the body and devour the remains (Holmes pers. comm.). Examples of eggs released in this fashion also occur in Polymorphus marilis, P. minutus and Acanthocephalus dirus (Nickol 1985). This mechanism of egg release would explain the many unattached $B$. balanae, with necks only, found in the lumen of the gut of this whale.

The genus Ogmogaster Jägerskiöld, 1891, currently contains 6 species, one of which $(O$. heptalineatus Carvajal \& George-Nascimento 1983) has been reported only from the South American sea lion Otaria flavescens Shaw. The other 5 (O. plicatus Jägerskiöld, 1891; O. grandis Skjrabin, 1969; O. trilineatus Rausch and Rice, 1970; O. antarcticus Johnston, 1931 and O. pentalineatus Rausch \& Fay, 1966) have all been found in baleen whales. $O$. pentalineatus has been reported only from Eschrichtius robustus, while O. antarcticus has been reported from both hemispheres and pinniped hosts, as well as the fin Balaenoptera physalus, sei $B$. borealis and bowhead Balaena mysticetus whales (Rausch \& Fay 1966, Shults 1979). Rausch \& Fay (1966) reviewed previously collected specimens of Ogmogaster and concluded that the taxonomic status of $O$. antarcticus should be reconsidered. When all the trematodes from previous collections were treated as a single series, dimensions of the body and number of ventral ridges showed a bimodal distribution, indicating 2 morphologically distinct entities. During this study we examined this possibility with our subsample of $O$. antarcticus, by looking at the relationship between body size and numbers of ventral ridges and marginal body crenulations $(n=100)$. We found no separation of morphotypes in our subsample. However, we did find that the number of marginal crenulations was a function of body size, while number of ventral ridges were not. Our smallest specimen (3.9 mm, n = 1) had the least crenulations of all specimens, 26 (mean = 29.4), but was above the mean with 14 ventral ridges (mean $=13.5, \mathrm{n}=12)$. 
Ogmogaster pentalineatus, as described by Rausch \& Fay (1966) and reported by Rice \& Wolman (1971), does not exceed $3.5 \mathrm{~mm}$ in length. Our small specimens with marginal crenulations measured $2.3 \mathrm{~mm}$ whereas those without were greater than $5 \mathrm{~mm}$. Specimens reaching $5.6 \mathrm{~mm}$ were reported by Rausch \& Rice (1971), but they did not mention the presence or absence of crenulations. The significance of these crenulations is unknown at present but they presumably play a role in mucosal attachment. While those located in the intestine embedded between the mucosal folds as shown in Fig. 7 by Rausch \& Fay (1966) would be aided by a rough body surface, those found in the smooth walled rectum (Rausch \& Rice 1971) would tend not to be so advantaged. Although the life cycle of Ogmogaster spp. has not been demonstrated, other members of the family Notocotylidae that infect marine hosts, such as those in the genus Notocotylus Diesing 1839, use a prosobranch snail for cercaria production, with the metacercaria encysting on vegetation (Stunkard 1966). This life cycle would be consistent with the stomach content findings in this gray whale.

Adult Anisakis spp. are parasites of the stomach and intestine of pinnipeds and cetaceans. The life cycle involves the passing of eggs by the marine mammal, hatching as second-stage larvae in seawater, ingestion by a marine crustacean in which they develop to the infective third-stage, followed by ingestion of the crustacean by teleost fishes or squid. Marine mammals can acquire larvae from eating infected fish, crustaceans or squid (Anderson 1992). In the case of Eschrichtius robustus, the worms can be readily transmitted by benthic infaunal crustaceans or those attached to vegetation, although all routes are possible based on recorded prey species (Nerini 1984). The only previous report from $E$. robustus is of a few immature $A$. simplex in the stomach of a juvenile male taken off the Washington coast in April of 1968 (Rice \& Wolman 1971). In contrast, the stomach of this whale contained massive numbers of immature worms (less that $20 \mathrm{~mm}$ ), mature males and gravid females. Thus, although common in marine mammals in Northeastern Pacific waters (Margolis \& Arai 1988, Anderson 1992), this is the first report of mature Anisakis spp. from E. robustus.

This gray whale was unique in that it was found alive in the surf prior to stranding. It presented a rare opportunity to examine associations between hematological and serum biochemical parameters, prey, parasite infestation and pathology in one animal. However, it is impossible to determine the significance of these findings in this single stranding to mortality in the eastern gray whale population without examination of other carcasses and further environmental and population parameters.
Acknowledgements. We thank Steve Sinnett and the Point Reyes National Seashore rangers for assistance with the necropsy. Bob Jones, Caitlyn Toropova, Leilane Stelle, Carol Stack, Jan Roletto, Michelle Lander and Brad Fenwick are thanked for literature and technical help.

\section{LITERATURE CITED}

Anderson RC (1992) Nematode parasites of vertebrates their development and transmission. CAB International, Wellingford

Bossart GD, Dierauf LA (1990) Marine mammal clinical laboratory medicine. In: Dierauf LA (ed) Handbook of marine mammal medicine. CRC Press, Boca Raton, FL, p 1-52

Dailey MD (1996) Essentials of parasitology, 6th edn. Wm C Brown, Dubuque, IA

Dailey MD, Brownell RL (1972) A checklist of marine mammal parasites. In: Ridgway S (ed) Mammals of the sea: biology and medicine. Thomas Press, Springfield, IL, p 528-589

Dailey M, Stroud R (1978) Parasites and associated pathology observed in cetaceans stranded along the Oregon coast. J Wildl Dis 14:503-511

Dailey M, Walker WA (1978) Parasitism as a factor in single strandings of Southern California cetaceans. J Parasitol 64:593-596

Darling JD, Keogh KE, Steeves TE (1998) Gray whale (Eschrichtus robustus) habitat utilization and prey species off Vancouver island, B.C. Mar Mamm Sci 14:692-720

Geraci JR (1978) The enigma of marine mammal strandings. Oceanus 21:38-47

Gershwin ME, Richard BS, Hurley LS (1985) Nutrition and immunology. Academic Press, London

Gilmartin WG, Pierce RW, Antonelis GA (1974) Some physiological parameters of the blood of the California gray whale. Mar Fish Rev 36:28-31

Margolis L, Arai HP (1988) Parasites of marine mammals. In: Kennedy MJ (ed) Synopsis of vertebrates of Canada. Alberta Agriculture Animal Health Division, Edmonton

Nerini M (1984) A review of gray whale feeding ecology. In: Jones ML, Swartz SL, Leatherwood S (eds) The gray whale, Eschrichtus robusuts. Academic Press, Inc, New York, p 423-448

Nickol BB (1985) Epizootiology. In: Compton DWT, Nickol BB (eds) Biology of the Acanthocephala. Cambridge University Press, Cambridge, p 307-346

Oliver JS, Slattery PN, Silberstein MA, O'Connor EF (1984) Gray whale feeding on dense ampeliscid amphipod communites near Bamfield, British Columbia. Can J Zool 62: 41-49

Pike GC (1962) Migration and feeding of the gray whale (Eschrichtus robustus). J Fish Res Board Can 19:815-838

Rausch RL, Fay FH (1966) Studies on the helminth fauna of Alaska. XLIV. Revision of Ogmogaster Jagerskiold, 1891, with a description of $O$. pentalineatus sp. n. (Trematoda: Notocotylidae). J Parasitol 52:26-38

Rausch RL, Rice DW (1971) Ogmogaster trilineatus sp. n. (Trematoda: Notocotylidae) from the fin whale, Balaenoptera physalus L. Proc Helminthol Soc Wash 37:196-200

Rice DW, Wolman AA (1971) The life history and ecology of the gray whale (Eschrichtius robustus). Am Soc Mamm (Spec Publ) 3:1-142

Rowles T (1999) Recent gray whale mortalities on the west coast. Mar Mamm Protection Assoc Bull 16:7

Scammon C (1869) The cetaceans of the western coast of Northern America. Proc Acad Natl Sci 21:40-49 
Schmidt GD (1985) Development and life cycles. In: Compton DW, Nickol BB (eds) Biology of the Acanthocephala. Cambridge University Press, Cambridge, p 273-286

Shults LM (1979) Ogmogaster antarcticus Johnston, 1931 (Trematoda: Notocotylidae) from the bowhead whale, Balaena mysticetus L., at Barrow Alaska. Can J Zool 57:1367-1368

Stunkard HW (1966) The morphology and life-history of Notocotylus atlanticus $\mathrm{n}$. sp., a digenetic trematode of eider ducks Somateria mollissima, and the designation Notocotylus duboisi nom. nov., for Notocotylus imbricatus (Looss, 1893) Szidat, 1935. Biol Bull 131:501-515

Sumich JL (1992) An introduction to the biology of marine life, 5th edn. Wm C Brown, Dubuque, IA

Sumich JL (1984) Gray whales along the Oregon coast in summer, 1977-1980. Murrelet 65:33-40

Editorial responsibility: Otto Kinne (Managing Editor), Oldendorf/Luhe, Germany
Sund PN (1975) Evidence of feeding during migration. J Mamm 56:250-266

Thomson CA, Geraci JR (1986) Cortisol, aldosterone and leucocytes in the stress response of bottlenose dolphins, Tursiops truncatus. Can J Fish Aquat Sci 43:1010

Thornton SM, Nolan S, Gulland FMD (1998) Bacterial isolates from California sea lions (Zalophus californianus), harbor seals (Phoca vitulina) and northern elephant seals (Mirounga angustirostris) admitted to a rehabilitation center along the central California coast, 1994-1995. J Zoo Wildl Med 29:171-176

Van Cleave HJ (1953) Acanthocephala of North American mammals. The University of Illinois Press, Urbana, IL

Zimushko YV, Lenskaya SA (1970) Feeding of the gray whale (E. gibbosus Erx.) at foraging grounds. Ekologiya 1:26-35

Submitted: February 2, 2000; Accepted: May 17, 2000

Proofs received from author(s): August 2, 2000 